ROCZNIKI HISTORYCZNE

Rocznik LXXXII - 2016

SOBIESŁAW SZYBKOWSKI (Uniwersytet Gdański, Gdańsk)

\title{
List Wawrzyńca Tariego, stolnika królowej Barbary Cylejskiej, do marszałka Królestwa Polskiego Zbigniewa z Brzezia z 13 VII 1413 roku
}

\begin{abstract}
Zarys treści: Publikowany list jest jednym z niewielu zabytków korespondencji elit środkowoeuropejskich XV w. Wawrzyniec Tari poleca w nim Zbigniewowi służby nieznanego bliżej Mikołaja zw. Altamont. List nie dotarł zapewne do odbiorcy ze względu na walki na pograniczu polsko-krzyżackim i trafił do archiwum krzyżackiego.
\end{abstract}

Content outline: The letter published here is one of very few surviving examples of correspondence of Central-European elites of the $15^{\text {th }}$ century. Laurentius Tari recommended to Zbigniew the services of one Nicolaus called Altamont. The letter probably did not reach the addressee because of the fights on the Polish-Teutonic borderland and found its way to the Teutonic Order's archives.

Słowa kluczowe: Polska, Węgry, korespondencja, elity rycerskie, peregrynacje

Keywords: Poland, Hungary, correspondence, elites, knights, peregrinations

Osobiste kontakty późnośredniowiecznego możnowładztwa polskiego nie tylko z możnymi z krajów ościennych, ale również pomiędzy sobą, są bardzo słabo poświadczone w źródłach. Wynika to z nienajlepszego stanu zachowania w środkowoeuropejskich archiwach prywatnej korespondencji, podstawowej kategorii przekazów, dokumentującej tego rodzaju kontakty ${ }^{1}$. Ta niedogodność doprowadziła nawet ostatnio do wysunięcia przypuszczenia, że piętnastowieczni możnowładcy polscy i litewscy nie nawiązywali relacji prywatnych². Wydaje się zatem, że zasadne

${ }^{1}$ O stanie zachowania polskiej korespondencji średniowiecznej wraz z bardzo kompetentnym wyliczeniem jej edycji źródłowych zob. Wstęp, w: Korespondencja żupnika krakowskiego Mikołaja Serafina z lat 1437-1459, wyd. W. Bukowski, T. Płóciennik, A. Skolimowska, Kraków 2006, s. VI-XII, a także T. J u re k, Pismo w życiu społecznym Polski późnego średniowiecza, w: Historia społeczna późnego średniowiecza. Nowe badania, Warszawa 2011, s. 228-230.

${ }^{2}$ R. P e tra u skas, Związki personalne między możnowładztwem Polski i Litwy od końca XIV do połowy XVI wieku, w: Narodziny Rzeczypospolitej. Studia z dziejów średniowiecza i czasów wczesnonowożytnych, Kraków 2012, s. 488-489. Teza ta została oparta głównie na braku zachowanej wzajemnej korespondencji prywatnej pomiędzy możnowładztwem polskim i litewskim, choć zachowały się listy Litwinów do urzędników krzyżackich oraz rad miejskich Gdańska i Rygi. Argument nie jest jednak przekonujący, ponieważ bardzo podobna sytuacja występuje w przypadku możnych polskich, których liczne listy do krzyżaków 
jest publikowanie nawet pojedynczych przekazów tego rodzaju jako świadectw istnienia owych osobistych relacji (niekiedy nawet dość bliskich) pomiędzy możnymi późnośredniowiecznej Europy Środkowej. Źródłem takim jest niewątpliwie list, zachowany w jednym z największych chyba zespołów późnośredniowiecznej epistolografii środkowoeuropejskiej (choć z wielką przewagą przekazów z północnej części tego regionu), przechowywanym obecnie w Geheimes Staatsarchiv Preussischer Kulturbesitz w Berlinie-Dahlem, a pochodzącym z dawnego archiwum wielkich mistrzów zakonu krzyżackiego ${ }^{3}$. Wydawcy drukowanego inwentarza tego zasobu, Erich Joachim i Walter Hubatsch, umieścili go w grupie źródeł niedatowanych (,undatierte Stücke”), ze względu na brak daty rocznej w datacji oraz brak innych przesłanek, które pozwoliłby ową datę ustalić ${ }^{4}$. Odbiorcą interesującego nas listu był marszałek Królestwa Polskiego Zbigniew z Brzezia, wystawcą natomiast: Laurencius Ratoldi de Pastoch magister dapiferorum reginalium Romanorum et Ungarie ac comes Hontiensis, zatem osoba, którą bez wątpienia należała do możnowładztwa węgierskiego, skoro przedstawiła się m.in. jako żupan komitatu Hont. Jej bliższa identyfikacja łączy się nierozerwalnie z dokonaną przez nas w dalszej części próbą ustalenia daty rocznej źródła. Wystawca informował, że jest zdrów i w dobrym nastroju, co chciałby też często słyszeć o odbiorcy. W dalszej części listu wystawca polecił odbiorcy „urodzonego męża” Mikołaja zwanego Altamont, który służył mu wiernie i z honorem, co potwierdzone zostało dodatkowymi dokumentami wystawionymi w jego interesie. List datowany jest in Utino w poniedziałek po dniu św. Małgorzaty, kończy się zaś intytulacją wystawcy. Z formalnego punktu widzenia

i rozmaitych rad miejskich zachowały się do chwili obecnej, bardzo niewiele przetrwało natomiast listów kierowanych przez możnych i szlachtę polską do siebie. O tym, że kontakty osobiste pomiędzy możnymi litewskimi i polskimi były zawiązywane, a korespondencja pomiędzy nimi krążyła, przekonuje choćby to, że o uwolnienie jeńców wywodzących się z wybitnych rodzin litewskich, wziętych do niewoli pod Chojnicami we wrześniu 1454, zabiegał w 1455 r. ówczesny starosta grudziądzki Jan ze Szczekocin (młodszy), który proponował wielkiemu mistrzowi ich wymianę na jeńców krzyżackich. Interwencja ta musiała zostać poprzedzona korespondencją z Litwą, ponieważ do swojego pisma do Malborka załączył on cedułę z imienną listą litewskich jeńców, których uwolnienia oczekiwał (Berlin-Dahlem, Geheimes Staatsarchiv Preußischer Kulturbesitz, Ordensbriefarchiv [dalej cyt.: OBA], nr 13771). Akcja była niewątpliwie zapoczątkowana prośbami (zapewne pisemnymi) krewnych pojmanych, z których wielu poznał osobiście, gdy jako młody rycerz przebywał na dworze wielkiego księcia Witolda w końcu lat dwudziestych XV w. - zob. S. S z y b k ow ski, Rycerscy goście z Polski na dworze wielkiego księcia Witolda - próba portretu grupy, w: Litwa i jej sąsiedzi w relacjach wzajemnych (XIII-XVI w.), Olsztyn-Gdańsk 2014, s. 92.

3 OBA, nr 29049a, list publikujemy w aneksie.

${ }^{4}$ Regesta historico-diplomatica Ordinis S. Mariae Theutonicorum 1198-1525, wyd. E. Joachim, W. Hubatsch, t. I, cz. 3, Göttingen 1973, nr 29049a. O znaczeniu informacyjnym „pozycji niedatowanych”, rzadziej wykorzystywanych przez badaczy niż pozostała korespondencja z OBA, zob. S. J ó ź w i a k, Wywiad i kontrwywiad w państwie zakonu krzyżackiego. Studium nad sposobami pozyskiwania i wykorzystywania poufnych informacji w późnym średniowieczu, Malbork 2004, s. 7, przyp. 1; S. S z y b k ow s k i, Wielka potrzeba dokumentu. List starosty dobrzyńskiego Janusza z Kościelca do komtura golubskiego w sprawie dokumentu dotyczącego wsi Grabowo w ziemi dobrzyńskiej, Rocznik Łódzki 61, 2014, s. $165-173$. 
jest to list klasyczny - zamknięty. Adres znajduje się in dorso, a pieczęć (wykonana w technice wosk przez papier) zamykała pismo ${ }^{5}$.

Ze względu na konieczność ustalenia daty rocznej listu oraz poprawnego zidentyfikowania miejsca jego wystawienia należy przyjrzeć się bliżej osobom korespondentów. Osobą łatwiejszą do identyfikacji jest odbiorca: Zbigniew z Brzezia i Lanckorony herbu Zadora, którego biografia wydaje się dość dobrze rozpoznana. Zbigniew był jednym z trzech synów Przedbora z Brzezia, który swoją karierę rozpoczą jako dworzanin Kazimierza Wielkiego. Od wspomnianego monarchy Przecław otrzymał stosunkowo niski urząd ziemski podstolego krakowskiego (1366-1370) oraz tenutę ogrodzieniecką, został również wraz z braćmi uwzględniony w testamencie ostatniego Piasta na tronie polskim. Jego znaczący awans był jednak możliwy dopiero dzięki bliskim relacjom, jakie nawiązał z królem Ludwikiem Andegaweńskim oraz jego matką, Elżbietą Łokietkówną, która była namiestniczką syna w jego północnym władztwie. To niewątpliwie z jej rekomendacji Ludwik mianował Przedbora na urząd marszałka Królestwa, piastowany w latach 1375-1378 oraz 1381-1387. Ten sam urząd sprawował też od 1399 r. Zbigniew Przedborowic z nominacji Władysława Jagiełły. Jako bliski współpracownik tego monarchy (w literaturze przedmioty zalicza się go do stronnictwa dworskiego) aktywnie działał aż do śmierci w 1425 r. Podkreślić przy tym trzeba jego znaczące zaangażowanie w różnego rodzaju misje dyplomatyczne do krajów ościennych i dalszych. Obok marszałkostwa Zbigniew otrzymał od Jagiełły także starostwo krakowskie (1409-1410), toruńskie (sprawowane przezeń krótko podczas wojny z Krzyżakami w 1. 1410-1411), dobrzyńskie (1411-1413), wreszcie tenuty lanckorońską i lelowską. Kariera Zbigniewa ugruntowała pozycje Zadorów z Brzezia w elicie możnowładczej Królestwa Polskiego, co kontynuowali jego potomkowie ${ }^{6}$.

5 Jako interesujące z porównawczego punktu widzenia należy wskazać edycje pism (w tym listów polecających) dotyczących peregrynacji kastylijskiego rycerza Alfonsa Mudarry oraz rycerzy pruskich Jana Marschalka i Jana z Targowiska (von Targowitz), zob. W. P a r a v i c i n i, Fürschriften und Testimonia. Der Dokumentationskreislauf der spätmittelalterlichen Adelsreise am Beispiel des kastilischen Ritters Alfonso Mudarra 1411-1412, w: Studien zum 15. Jahrhundert. Festschrift fur Erich Meuthen, t. II, München 1994, s. 903-936; S. C. R o w e 11, Du Europos pakraščiai: Lietuvos Didžiosios Kunigaikštystès ir ispanų karalysčių ryšiai 14111412 m. tekstuose, Lietuvos istorijos metraštis 2003, nr 1, s. 159-172, 187-188; należy jednak zwrócić uwagę, że wystawcami i odbiorcami większość z nich byli panujący.

${ }^{6}$ O karierze Przedbora i Zbigniewa z Brzezia zob. Urzędnicy małopolscy XII-XV wieku. Spisy, Wrocław 1990, s. 288, 324; Urzędnicy centralni i nadworni Polski XIV-XVIII wieku. Spisy, Kórnik 1992, s. 77, 78, 160; Urzędnicy kujawscy i dobrzyńscy XII-XV wieku. Spisy, Kórnik 2014, s. 294, 256, 301-302; A. S tr z e le c k a, Lanckoroński Zbigniew, w: Polski słownik biograficzny, t. XVI (1971), s. 457-458; J. W y r o z u m s k i, Przedbor z Brzezia, w: tamże, t. XXVIII (1985), s. 698-699; J. G z e 11 a, Małopolska elita władzy w okresie rządów Ludwika Węgierskiego w Polsce w latach 1370-1382, Toruń 1994, s. 21-22; S. G a w ę d a, Początki i rola rodziny Lanckorońskich do końca średniowiecza, Zeszyty Naukowe Uniwersytetu Jagiellońskiego, Prace Historyczne, z. 89, 1989, s. 53-65; S. C y n a r s k i, Dzieje rodu Lanckorońskich z Brzezia od XIV do XVIII wieku, Warszawa 1996, s. 21, 24-26, 39, 42-44, 45, 53-62, 64-79, 221, 253, 257-263; J. S p e r k a, Szafrańcowie herbu Stary Koń. Z dziejów kariery i awansu w późnośredniowiecznej Polsce, Katowice 2001, s. 269-270; A. M a r z e c, Urzędnicy małopolscy w otoczeniu Władysława Łokietka i Kazimierza Wielkiego (1305-1370), 
Wystawca przedstawił się, przypominamy, jako Laurencius Ratoldi de Pastoch magister dapiferorum reginalium Romanorum et Ungarie ac comes Hontiensis. W okresie sprawowania przez Zbigniewa z Brzezia urzędu marszałka (1399-1425) tylko jedna osoba o imieniu Wawrzyniec notowana była jako stolnik królowej Węgier?: był to Wawrzyniec (Lőrinc) Tari (Rátoti, Pásztói). Był on synem Władysława (Laszlo) Tariego, znanego źródłom w latach 1347-1397, rycerza dworu królowych Elżbiety Bośniaczki i Marii Andegaweńskiej (1381-1391), a następnie żupana komitatu Heves (1393). Młodszy Tari występował w źródłach od 1389 do 1426 r. Na początku XV w. źródła ukazują go jako osobę blisko związaną z Zygmuntem Luksemburskim jako królem Węgier. Wawrzyniec należał bowiem do tych węgierskich możnych, którzy podczas pasma buntów przeciwko Zygmuntowi z lat 1401-1403 zdecydowanie stanęli po stronie monarchy. Jego zasługi dla Luksemburczyka nie polegały jednak wyłącznie na udzieleniu politycznego poparcia. Młody Tari jako jedyny z rycerzy dworu królewskiego mieczem próbował obronić swego władcę przed buntownikami, którzy 28 IV 1401 r. pojmali króla na zamku Budzie. Dopiero pięciokrotnie zraniony uległ węgierskim baronom i tylko pomocy lekarzy (na których opłacenie wydał znaczną część majątku) zawdzięczał powrót do zdrowia. Po budzińskich wydarzeniach pozostała mu jednak do końca życia widoczna pamiątka: pokaźna blizna na rozciętym mieczem nosie. Zygmunt (uwolniony późnym latem 1401 r.) ostatecznie jednak uporał się ze swoimi przeciwnikami i zaczął wynagradzać swojego wiernego rycerza. Wawrzyniec już w 1404 r. był relatorem jednego z dokumentów królewskich, wówczas także został po raz pierwszy poświadczony jako królewski cześnik (magister pincernarum regalium), którym był do 1406 r., a także żupan komitatu Nógrádu (do 1413 r.). W 1. 1406-1413 był również żupanem komitatu Hont. Od 1407 r. występował jako urzędnik dworu małżonki Zygmunta, królowej Barbary Cylejskiej: jej cześnik (magister pincernarum reginalium) w 1. 1407-1409 oraz stolnik w 1. 1407-1413. Po rezygnacji z urzędów na dworze królowej pozostawał nadal w bliskich relacjach z Zygmuntem. Był obecny podczas jego akwizgrańskiej koronacji w 1414 r., w tym roku został nawet określony jako jego doradca. Wraz z królem brał udział w soborze konstancjańskim, a być może także w jego podróżach dyplomatycznych do Francji i Anglii, które miały miejsce podczas obrad soborowych. Po powrocie na Węgry nie widać jednak, żeby pełnił kolejne urzędy (w źródłach był tytułowany tylko jako „rycerz”), choć żył do 1426 r. Wycofanie się Tariego z życia dworskiego mogło być spowodowane pogarszającym się stanem zdrowia; być może odezwały się ciężkie rany odniesione $\mathrm{w}$ obronie króla $\mathrm{w} 1401 \mathrm{r}$. Wawrzyniec był również sprawnym dyplomatą Zygmunta (o czym niżej), tudzież pielgrzymem. W 1408 r. wybierał się do Santiago de Compostella w Hiszpanii, w związku z czym otrzymał list polecający

Kraków 2006, według indeksu; A. S z w e d a, Organizacja i technika dyplomacji polskiej w stosunkach z zakonem krzyżackim w Prusach w latach 1386-1454, Toruń 2009, według indeksu.

7 Tak interpretujemy nazwę urzędu sprawowanego przez Tariego, choć oryginalne określenie łacińskie (magister dapiferorum) i jego węgierskie tłumaczenie (,,asztalnokmester") sugerowałoby, że także po polsku należałoby użyć formy „mistrz stolników”; por. J. K. H o e n s c h, Kaiser Sigismund. Herrscher an der Schwelle zur Neuzeit 1368-1437, München 1996, s. 170, 650 („Truchsess Barbaras von Cilli”); D. D v o ř á k o v a, Rytier a jeho král’. Stibor zo Stiboric a Žigmund Luxemburský, Budmerice 2003, s. 524 („stolník král’ovnej”). 
Zygmunta. W 1411 r. odwiedził Purgatorium św. Patryka w Irlandii, gdzie doznał wizji, które zostały spisane w specjalnym akcie notarialnym sporządzonym w Dublinie. Dodać należy, że do celu swojej pielgrzymki udał się przez Anglię, z której wrócił dopiero w 1412 r., przy czym węgierski badacz A. Bárány przypuszcza, że Tari pod pozorem pobożnej peregrynacji wypełniał tam misję dyplomatyczną $\mathrm{w}$ interesie Zygmunta. W początku 1413 r. Wawrzyniec miał zamiar jeszcze odbyć podróż do Ziemi Świętej, w związku z czym 28 stycznia tr. uzyskał od Wenecjan salvus conductus. Nie wiadomo jednak, czy istotnie tam się udał, ponieważ jego ówczesny pobyt w Wenecji był w rzeczywistości związany z tajnymi rokowaniami z ramienia Zygmunta. Szczególną pobożność oraz wysoki status Wawrzyńca wśród baronów Królestwa Węgier podkreśla także fakt posiadania przezeń kosztownych relikwii (trzy drzazgi z drzewa Krzyża Św. oraz trzy strzępki szaty Chrystusa), które nosił przy sobie w kosztownym relikwiarzu ze złota i srebra, wysadzanym drogimi kamieniami. Wawrzyniec prezentował wreszcie dość rzadkie umiejętności językowe, miał bowiem znać hebrajski i grekę. Korespondenta Zbigniewa z Brzezia można zatem z całą pewnością określić nie tylko jako bliskiego współpracownika króla Zygmunta, ale również jako osobowość niepospolitą wśród całego węgierskiego możnowładztwa. Synem Wawrzyńca był Rupert, znany od 1423 r., w 1. 1432-1433 występujący zaś jako dworzanin królewski (aulicus). Po śmierci Zygmunta został (1438) koniuszym królowej Elżbiety Luksemburskiej (magister agasonum reginalium), nadto sprawował urząd żupana komitatu Heves (1441). Pozostawał, jak się wydaje, w dość bliskich relacjach z Janem Hunyadim jako regentem Królestwa Węgier, skoro w 1447 r. był relatorem jednego z wystawionych przezeń dokumentów. Karierę Ruperta Tariego przerwała przedwczesna śmierć w $1448 \mathrm{r}^{8}{ }^{8}$

Skrótowe życiorysy korespondentów pozwalają nam na zawężenie datacji interesującego nas listu do lat 1411-1413. Wawrzyniec Tari sprawował bowiem urząd stolnika królowej Barbary w 1. 1409-1413. Czas ten możemy zawęzić jeszcze o dwa lata ze względu na fakt zachowania się listu w archiwum krzyżackim. Mógł on znaleźć

${ }^{8}$ O karierach i związkach rodzinnych Władysława, Wawrzyńca i Ruperta Tarich zob. P. En g e 1, Magyarország világi archontológiája 1301-1457, t. I, Budapest 1996, s. 45, 58, 59, 135, 137, 158, 306, 411, 487, 496, 506, 524; t. II, s. 239-240; J. C a b a 11 o, A tari késő-közepkori udvarház, Castrum Bene 2, 1990, s. 227-228; D. D v o ř á k o vá, Rytier, s. 78, 157, 338, 356, 357, 446, 460; A. B á r á n y, Zsigmond király 1416-os angliai kísérete, Aetas 19, 2004, nr 3-4, s. 7; t e n ż e, Political pilgrimage in later medieval Central Europe: a case study of a Hungarian traveller to Ireland, w: Europe and the World. Travel, Migration, Exploration, Pisa 2010, s. 109-120; Wawrzyńcowi Tariemu poświęcona jest także obszerna strona w węgierskiej wersji Wikipedii: https://hu.wikipedia.org/wiki/Tari_L\%C5\%91rinc (dostęp 5 VII 2016); głęboka pobożność Wawrzyńca zdaje się znajdować dodatkowe potwierdzenie w fakcie, że jego herb został umieszczony w wieńcu z korony cierniowej (zob. opis pieczęci w aneksie). Tariego wspomina także powstała w XVI w. wierszowana kronika Sebastiana Tinódiego o Zygmuncie Luksemburskim. Dziejopis ten wykorzystał powstałą wcześniej węgierską baśń o wyprawie Wawrzyńca do piekła, gdzie ten miał spotkać cierpiącego męki Luksemburczyka, ukaranego wiecznym potępieniem za zbytnią skłonność do pięknych kobiet; opowieść ta wydaje się refleksem widzenia, którego stolnik królowej Barbary doznał w Purgatorium św. Patryka w 1411 r. - zob. Tar Lőrinc pokoljárása. Középkori magyar víziók, wyd. Gy. Belya, Budapest 1985; D. D v o ř á k o v á, Čierna král'ovná. Barbora celjská (1392-1451), Budmerice-Bratislava 2013, s. 29. 
się tam najpewniej wtedy, kiedy odbiorca (do którego pismo najwyraźniej nie dotarło) był związany w jakiś sposób z pograniczem polsko-krzyżackim. Zbigniew z Brzezia był zaś starostą dobrzyńskim właśnie w latach 1411-1413 ${ }^{9}$. Był to okres, kiedy na pograniczu polsko-krzyżackim, pomimo zawarcia pokoju toruńskiego w $1411 \mathrm{r}$., było bardzo niespokojnie ${ }^{10}$. Krzyżackimi najazdami była wówczas niepokojona również ziemi dobrzyńska i to zapewne podczas jednego $\mathrm{z}$ nich list skierowany do Zbigniewa trafił w ręce krzyżackie i został przekazany do wielkomistrzowskiego archiwum do Malborka ${ }^{11}$.

Największy najazd krzyżacki w interesującym nas okresie dotknął ziemię dobrzyńską we wrześniu 1413 r., w okresie, kiedy wielki mistrz Henryk von Plauen zamierzał rozpocząć nową wojnę z Polską i Litwą, czemu zapobiegło usunięcie go z urzędu i uwięzienie na początku października przez wewnętrzną opozycję na czele z wielkim marszałkiem Michałem Küchmeistrem ${ }^{12}$. Zgodnie z polskimi artykułami oskarżenia przedstawionymi na procesie budzińskim w 1414 r., szkody, jakie poniósł król Władysław Jagiełło i starosta dobrzyński Zbigniew z Brzezia w wyniku spustoszenia przez wojska zakonne, miały wynosić 3000 grzywien polskich, starosta był zaś jeszcze zmuszony do wydania 1000 grzywien na opłacenie zbrojnych, których zaciągnął dla obrony powierzonej sobie ziemi ${ }^{13}$.

Za datowaniem listu Tariego do Zbigniewa na 1413 r. przemawia także miejsce jego spisania. Został on bowiem wystawiony in Utino, co zidentyfikować można najłatwiej z Udine w północnowłoskiej prowincji Friuli. Pozwala to raczej wykluczyć lata 1411 i 1412, kiedy Wawrzyniec pielgrzymował do Irlandii; jego obecność tam źródła poświadczają w listopadzie 1411, w Anglii natomiast jeszcze w kwietniu 1412 r. ${ }^{14}$ Obecność Wawrzyńca w północnej Italii potwierdzona jest natomiast właśnie w 1413 r. Było to związane z kolejną odsłoną ciągnącego się już od kilku lat

${ }^{9}$ Urzędnicy kujawscy i dobrzyńscy, s. 295.

${ }_{10}$ M. B i s k u p, Wojny polski z zakonem krzyżackim 1308-1521, Gdańsk 1993, s. 95-97; W. Si e radzan, Sąsiedztwo mazowiecko-krzyżackie w okresie przemian politycznych w Europie Środkowo-Wschodniej w latach 1411-1466, Toruń 1999, s. 22-26; B. M o ż e j k o, Ród Świnków na pograniczu polsko-krzyżackim w średniowieczu, Gdańsk 1998, s. 110-112; A. S z w e d a, Polsko-krzyżackie kontrowersje na Krajnie w latach 1411-1422, w: Europa Środkowo-Wschodnia. Ideologia, historia a społeczeństwo, Zielona Góra 2005, s. 202-207; t e n ż e, Zakon krzyżacki wobec Polski i Litwy w latach 1411-1414, Zeszyty Naukowe Uniwersytetu Jagiellońskiego, Prace Historyczne, t. 141, 2014, z. 2, s. 544-545.

${ }^{11}$ Raczej wątpliwe, aby Mikołaj Altamont pojechał z listem Tariego do stolicy krzyżackiej w Malborku. Jak staramy się uzasadnić dalej, był on zaciężnym poszukującym nowego zajęcia. Gdyby chciał zatrudnić się w Prusach, to na pewno nie pokazywałby tam listu polecającego adresowanego do wysokiego urzędnika polskiego.

12 W. Nöb e 1, Michael Küchmeister. Hochmeister des Deutschen Ordens 1414-1422, Marburg 1989, s. 59-68; B. M o ż e j k o, Ród Świnków, s. 110-112; A. S z w e d a, Zakon krzyżacki, s. 544-545.

${ }^{13}$ Lites ac res gestae inter Polonos ordinemque Cruciferorum, t. III, wyd. J. Karwasińska, Warszawa 1935, s. 125-126: Sbigneus Regni Polonie marschalcus--pro defensa terre predicte vocare et sallariare stipendiarios et gentes, quibus satisfaciendo pro stipendiis dampnificatus est in mille marcis grossorum Polonicalium numeri et monete et extimat ipsa dampna et stipendia ad mille marcas Polonicales.

${ }^{14}$ A. B á r á n y, Political Pilgrimage, s. 111. 
konfliktu Węgier z Republiką Wenecką, w którym działania zbrojne zostały wznowione w maju 1412 r. Wielka wyprawa do Friuli została przez Zygmunta przygotowana jesienią 1412 r. Król poprowadził ją osobiście, obserwując działania zbrojne z Udine od 15 XII 1412 r. Wobec ich niejednoznacznego wyniku już w styczniu 1413 r. Luksemburczyk rozpoczął poszukiwania pokojowego wyjścia z impasu. W tym celu do Wenecji został wysłany właśnie Wawrzyniec Tari, dowodnie obecny tam w dniach 20-28 stycznia. Przeprowadzenie przezeń półoficjalne rozmowy doprowadziły do uzyskania zgody Wenecjan na rozejm, który został formalnie zawarty w Castelleto 17 IV 1413 r. ${ }^{15}$

Datowanie przez nas listu Tariego do Wawrzyńca na rok 1413, co jego datę dzienną każe rozwiązać jako 10 lipca, nie musi stać w sprzeczności z tym, że 28 stycznia tr. otrzymał on od władz weneckich glejt na podróż do Ziemi Świętej. Wydaje się bowiem wątpliwe, żeby zdecydował się on na przeprawę morską przez Morze Śródziemne w okresie zimowym. Raczej pozostał on we Friuli do momentu formalnego zawarcia rozejmu w kwietniu, a najpewniej i później przebywał tam, aby nadzorować wchodzenie porozumienia w życie. Zygmunt bowiem opuścił Udine dopiero pod koniec maja 1413 r., po czym udał się przez północne Włochy do Trydentu i dalej do Rzeszy, gdzie bawił do września, aby ponownie wrócić do północnej Italii $^{16}$. Jeżeli zatem w ogóle doszło do pielgrzymki Tariego do Ziemi Świętej, gdyż sam zamiar nie musiał oznaczać jego rzeczywistej realizacji, to dopiero po 10 lipca, kiedy najpewniej przebywał jeszcze w Udine. Fragmentaryczne itinerarium Wawrzyńca zestawione przez Pála Engela, pokazuje, że 1 V 1414 r. był wraz z królem Zygmuntem w północnowłoskim Asti ${ }^{17}$.

Niewiele można natomiast ustalić w przypadku Mikołaja zwanego Altamont, którego usługi stolnik Wawrzyniec polecał polskiemu marszałkowi. Był na pewno szlacheckiego pochodzenia, skoro użyto w stosunku do niego tytulatury procreatus vir. Jego przynależność stanowa oraz fakt służby dla Wawrzyńca w okresie bezpośrednio po konflikcie zbrojnym pozwala wysunąć przypuszczenie, że był on zaciężnym w jego banderii, która walczyła z siłami weneckimi. Po zawarciu rozejmu Mikołaj poszukiwał zapewne nowego zajęcia ${ }^{18}$. To zapewne spowodowało, że jego dotychczasowy ,pracodawca” polecił go Zbigniewowi ${ }^{19}$. Potwierdzone źródłowo

${ }^{15}$ W. B a u m, Kaiser Sigismund. Hus, Konstanz und Türkenkriege, Graz-Wien-Köln 1993, s. 86-89; J. K. H o e n s c h, Kaiser Sigismund, s. 166-170; P. E n g e 1, Magyarország világi archontológiája, t. I, s. 496; P. Eng e 1, N. C. T ó th, Itineraria regum et reginarum (1382-1438), Budapest 2005, s. 95.

${ }_{16}$ J. K. H o e n s c h, Kaiser Sigismund, s. 172-174; P. En g e 1, N. C. T ó th, Itineraria, s. 96.

17 P. En g e 1, Magyarország világi archontológiája, t. I, s. 496.

18 Odrzucamy raczej możliwość, aby Mikołaj Altamont udawał się do Polski na rycerską peregrynację, wówczas bowiem list polecający byłby pozbawiony wzmianki o dodatkowych dokumentach potwierdzających ,jakość” usług Mikołaja oddanych wystawcy, zob. S. C. R ow e 11, Du europos pakraščiai, s. 159-160, 187-188.

${ }_{19}$ Marszałek Zbigniew już podczas przygotowań do letniej kampanii w Prusach dał się poznać jako zwolennik werbowania cudzoziemskich zaciężnych, zob. Joannis Dlugossii Annales seu cronicae incliti Regni Poloniae, lib. IX-X, Varsoviae 1997, s. 57-58; S. C y n a r s ki, Dzieje rodu Lanckorońskich, s. 69; S. Jóźwi a k, K. Kwiatkow ski, A. S zwe da, 
mamy rekrutowanie zaciężnych przez Zbigniewa w $1413 \mathrm{r}$. Zapobiegliwy starosta dobrzyński, wobec stopniowego zaostrzania się stosunków polsko-krzyżackich, rozpoczął prawdopodobnie zaciągi odpowiednio wcześniej.

Przydomek Mikołaja (Altamont) mógłby sugerować, że był on rycerzem z Włoch (może z Friuli?). Przypuszczenie to należy jednak traktować bardzo ostrożnie, ze względu na spotykany w średniowieczu pisarski zwyczaj tłumaczenia przydomków i przezwisk na język bliski pisarzowi (zazwyczaj chodzi o latynizację, choć w przypadku naszego listu możemy mieć do czynienia raczej już z italianizacją) ${ }^{20}$. Nie można zatem wykluczyć, że pochodził on z Rzeszy lub z krajów Korony św. Stefana ${ }^{21}$. Trudno również stwierdzić z całą pełnością, czy dotarł on do Polski i wszedł w służbę Zbigniewa z Brzezia ${ }^{22}$.

Skierowanie przez Wawrzyńca Tariego listu do Zbigniewa z Brzezia, zaopatrzonego w jego poprawną tytulaturę urzędniczą i przydomek posesjonatywny, świadczy

S. S z y b k o w s k i, Wojna Polski i Litwy z zakonem krzyżackim 1409-1411, Malbork 2010, s. 235 .

${ }^{20}$ Gwoli przykładu należy podać listę gwarantów krzyżackiego dokumentu brzeskiego z 1435 r. (Warszawa, Archiwum Główne Akt Dawnych, Zbiór dokumentów pergaminowych, nr 1011), w której dokonano latynizacji przydomków niektórych rycerzy nowomarchijskich: Arnold von der Walde (Wolde) stał się tam Arnoldem de Silva, a Henning von dem Borne Henningiem de Fonte; zob. także przyp. 21.

${ }^{21}$ Kwerenda dotycząca ewentualnych związków Altamonta (biorąc też pod uwagę niemiecką formę jego nazwiska w postaci Hochberg) z Królestwem Węgier w regestariuszu dokumentów węgierskich za lata 1400-1425 (Zsigmondkori oklevéltár, t. II-XII, wyd. I. Borsa, E. Mályusz, B. Lakatos, T. Neumann, N.C. Tóth, Budapest 1956-2013) nie przyniosła pozytywnych rezultatów. Zachęcający mógłby wydawać się ewentualny polski trop identyfikacji Mikołaja - de Altomonte był bowiem incydentalnie pisany w łacińskich źródłach kasztelan rozpierski Zbigniew Bąk z Wysokiej Góry (później Bąkowa Góra), zob. np.: Codex epistolaris saeculi decimi quiniti, t. II, wyd. A. Lewicki, Kraków 1891, nr 177, 178; Z. H. N o w a k, Współpraca polityczna państw unii polsko-litewskiej i unii kalmarskiej w latach 1411-1425, Toruń 1996, nr IV, Va, Vb, a jego syna, także Zbigniewa, w niemieckim liście z 1454 r. określono przydomkiem Hochberger (Regesta, t. I, cz. 1, Göttingen 1948, nr 12950). Starszy Zbigniew miał nawet przyrodniego brata Mikołaja (niepełnoletni zapewne jeszcze w 1402, zm. między 1421 a 1431 r.), który występował jako pasowany rycerz od 1419 r.; nie dziedziczył on jednak w Wysokiej Górze, którą w 1398 r. w wyniku podziału z ojcem Pakosławem otrzymał Zbigniew, lecz w Chełmie, Masłowicach, Ochotniku, Kalinkach i Korytnie w ziemi sieradzkiej (A. S z y m c z a k o w a, Dziedzice Bąkowej Góry w wieku XV, Rocznik Łódzki 50, 1993, s. 119-148; t a ż, Szlachta sieradzka w XV wieku. Magnifici et generosi, Łódź 1998, s. 356-377), nie mógł więc raczej używać przydomka urobionego od posiadłości starszego brata, nazwy Chełm nie oddawano by zaś jako Altus Mons (nie znają takich form poświęcone wsiom Chełm hasła w Słowniku historyczno-geograficznym województwa krakowskiego w średniowieczu, cz. I, z. 2, Wrocław 1983, s. 329, 331-333, 338). Przeciwko identyfikacji Mikołaja Altamonta z młodszym bratem kasztelana rozpierskiego Zbigniewa przemawia także to, że wystawca listu określił go w nim jedynie jako „urodzonego męża”, podczas gdy Mikołaj z Chełmu był dowodnym bratem stryjecznym adresata. Przy przyjęciu takiej identyfikacji trudno byłoby także zrozumieć celowość polecania „wiernych służb” Mikołaja jego bliskiemu krewnemu.

${ }^{22}$ List Wawrzyńca do Zbigniewa nie precyzuje wyraźnie, czy jego dostarczycielem miała być osoba polecana, czy też poprzedzał on jej dotarcie do Polski (za tą druga możliwością przemawia to, że Mikołaj miał okazać Zbigniewowi osobne dokumenty potwierdzające jego chwalebną służbę dla Tariego). 
bez wątpienia, że posiadał on co najmniej dobrą wiedzę o adresacie swojego pisma. Oczywiście nie musi to dowodzić, że łączyły ich bliższe relacje. Tari mógł po prostu napisać list polecający do Zbigniewa jako marszałka Królestwa, zajmującego się m.in. zarządem dworu polskiego monarchy. Wydaje się jednak, że przeczą temu kordialne zwroty użyte w liście w stosunku do marszałka (magnifice vir ac frater et amice carissime, fraternitas vestra), które pozwalają sądzić, że Wawrzyńca i Zbigniewa mogły łączyć relacje serdeczniejsze od urzędowych. Przy próbie objaśnienia tej kwestii warto zwrócić uwagę na aktywność dyplomatyczną marszałka Królestwa w latach poprzedzających otrzymanie przezeń listu od Tariego. Zbigniew dowodnie brał bowiem udział w trwających późną zimą i wczesną wiosną negocjacjach na terenie Górnych Węgier, które w 1411 r. doprowadziły do zawarcia rozejmu w konflikcie polsko-węgierskim. Układ ten zakończył formalnie krótkotrwałą wojną, wybuchłą na jesieni 1410 r., kiedy Zygmunt Luksemburski wsparł militarnie wojujących z Polską i Litwą Krzyżaków ${ }^{23}$. Być może jednym z węgierskich partnerów pana z Brzezia podczas tych rozmów był Wawrzyniec Tari i właśnie wówczas doszło pomiędzy nimi do nawiązania bliższych stosunków ${ }^{24}$. Marszałek uczestniczył również w zjeździe w Kieżmarku w marcu 1412 r., podczas którego zawarto pokój i sojusz z Zygmuntem Luksemburskim jako królem Węgier ${ }^{25}$, jednak wówczas raczej nie spotkał się z Wawrzyńcem, który jeszcze w kwietniu był w Anglii.

Może być jednak jeszcze jedno wytłumaczenie istnienia bliskich relacji łączących korespondentów. Jak już wspomniano, Wawrzyniec określał w swoim piśmie Zbigniewa „bratem”. Można oczywiście założyć, że było to związane tylko z bliskimi relacjami towarzyskimi. Znamy, nieliczne wprawdzie, przykłady z polskiej piętnastowiecznej korespondencji, że braćmi określano osoby, które nie były ze sobą spokrewnione czy spowinowacone. Zdarzyło się tak w kilku listach kierowanych z koronacyjnego zjazdu krakowskiego w 1434 r. przez możnych polskich do wielkiego mistrza zakonu krzyżackiego $^{26}$. W tym jednak przypadku interesujący nas termin frater miał najpewniej za zadanie podkreślenie jedności polskiej elity władzy, do czego doprowadził daleko idący polityczny kompromis między najważniejszymi ówczesnymi stronnictwami, który umożliwił koronację niepełnoletniego Władysława III $^{27}$. Pozbawione rzeczywistych konotacji wynikających z pokrewieństwa lub powinowactwa używanie terminów

${ }^{23}$ S. C y n a r s ki, Dzieje rodu Lanckorońskich, s. 72.

${ }^{24} \mathrm{O}$ wojnie polsko-węgierskiej towarzyszącej konfliktowi z krzyżakami i negocjacjach, które ją zakończyły zob. ostatnio S. Jóźwiak, K. Kwi atkowski, A. S zweda, S. S z y b k owsk i, Wojna Polski i Litwy, s. 656-668; S. A. S roka, Wojska węgierskie u granic Polski w 1410 roku, Studia Historyczne 53, 2010, s. 335-345.

${ }^{25}$ S. C y narski, Dzieje rodu Lanckorońskich, s. 72-73. Zbigniew nie był natomiast obecny podczas dalszej części wizyty Jagiełły na Węgrzech (która przeciągnęła się do lipca), ponieważ już 8 IV 1412 r. przebywał w Krakowie (W. P a r a vi c in i, Fürschriften, s. 923924; S. C. R o w e 11, Du Europos pakraščiai, s. 169-170).

${ }^{26}$ OBA, nr 6841-6843; S. S z y b k o w s ki, Kredytywa możnych polskich dla posłów do wielkiego mistrza Pawła Rusdorfa z 31 VII 1434 r. Z badań nad okresem rządów opiekuńczych w Królestwie Polskim w latach 1434-1438, Studia z Dziejów Średniowiecza 19, 2015 , s. 356-357.

27 A. S o c h a c k a, Jan z Czyżowa, namiestnik Władysława Warneńczyka. Kariera rodziny Półkozów w średniowieczu, Lublin 1993, s. 88-89; J. S p e r k a, Szafrańcowie, s. 243-244. 
dokumentujących te rodzinne relacje było jednak w polskiej korespondencji bardzo rzadkie. W zasadzie brak go np. w jednym z większych korpusów piętnastowiecznych polskich listów prywatnych i urzędowych związanych z osobą żupnika krakowskiego Mikołaja Serafina, ponieważ już określenie tego ostatniego „wujem” wyższego odeń statusem Jakuba z Sienna wywołało spekulacje o łączącym ich pokrewieństwie lub powinowactwie ${ }^{28}$. Trudno jednak dociec na tym etapie badań, jakiego rodzaju relacje rodzinne łączyły Zbigniewa z Brzezia i Wawrzyńca Tariego. Wiadomo, że żoną tego ostatniego była nieznana $\mathrm{z}$ imienia przedstawicielka austriackiej rodziny rycerskiej von Walsee ${ }^{29}$. Nie znamy natomiast pochodzenia i imienia pierwszej żony marszałka Zbigniewa; drugą była zaś Anna z Sadłowa herbu Świnka, wdowa po kasztelanie sandomierskim Tomaszu z Węgleszyna ${ }^{30}$. Nie można wykluczyć, że do nawiązania stosunków rodzinnych doszło już we wcześniejszym pokoleniu. Wiemy, że podczas grudniowej masakry Węgrów w Krakowie w 1376 r. ojciec Zbigniewa, marszałek Przedbor z Brzezia, ukrył w swoim domu dwóch węgierskich młodzieńców, ulubieńców królowej Elżbiety Łokietkówny, których jednak pod jego nieobecność zabili słudzy; może Przedbor uczynił to nie tylko dlatego, że chciał uzyskać wdzięczność matki króla Ludwika Andegaweńskiego ${ }^{31}$. Problem ten należy jednak na tym etapie pozostawić otwarty.

\section{TEKST LISTU}

Udine, [10 VII 1413]

Stolnik królowej rzymskiej i węgierskiej [Barbary Cylejskiej] Wawrzyniec Tari poleca marszałkowi Królestwa Polskiego Zbigniewowi z Brzezia urodzonego męża Mikołaja zwanego Altamont, który wiernie $i$ z honorem stużyt wystawcy. [Zastugi Mikołaja] lepiej ukaża odbiorcy specjalne dokumenty wystawione w jego interesie przez Wawrzyńca, [które Altamont przedstawi Zbigniewowi].

Or.: Berlin-Dahlem, Geheimes Staatsarchiv Preußischer Kulturbesitz, XX. HA, Ordensbriefarchiv, $n r$ 29049a, papier $224 \times 122 \mathrm{~mm}$; na zgięciach dwa niewielkie ubytki papieru, niemajace wplywu na odczyt tekstu; zamykajaca list pieczęć Wawrzyńca Tariego (wosk przez papier): kustodia $31 \times 29 \mathrm{~mm}$, na miejscu, odcisk o średnicy $28 \mathrm{~mm}$, w polu pieczęci czteropolowy herb wystawcy $w$ wieńcu z korony cierniowej, godła nieczytelne (zagniecione), legenda nieczytelna.

Reg.: Regesta historico-diplomatica Ordinis S. Mariae Theutonicorum 1198-1525, wyd. E. Joachim, W. Hubatsch, t. I, cz. 3, Göttingen 1973, nr $29049 a$.

${ }^{28}$ Korespondencja żupnika, nr 17, a także wstęp do tej edycji, s. XXV-XXVI.

${ }^{29}$ Zob. przyp. 8.

${ }^{30}$ J. K u r t y k a, O ,sumach sadłowskich” i rzekomym mariażu Lanckorońskich i Tęczyńskich w początkach XV w., w: Venerabiles, nobiles et honesti. Studia z dziejów społeczeństwa Polski średniowiecznej. Prace ofiarowane Profesorowi Januszowi Bieniakowi w siedemdziesiątą rocznicę urodzin i czterdziestopięciolecie pracy naukowej, Toruń 1997, s. 193-205.

${ }^{31}$ Kronika Jana z Czarnkowa, wyd. J. Szlachtowski, Monumenta Poloniae historica, t. II, Lwów 1872, s. 676-677; J. W y r o z u m s k i, Przedbor z Brzezia, s. 698-699; S. C y n a r s k i, Dzieje rodu Lanckorońskich, s. 60. 
Uwaga: Tekst wydany wedtug zasad zawartych w: A. Wolff, Projekt instrukcji wydawniczej dla pisanych źródeł historycznych do połowy XVI wieku, Studia Źródłoznawcze 1, 1957, s. 155-181. Osoby objaśnione w tekście artykułu.

${ }^{a}$-Magnifico et potenti viro, | domino Swignew de Brez marescalco | Regni Polonie, fratri et amico $\mid$ meo carissimo ${ }^{-b}$

${ }^{c}\|\mathrm{M}\|$ agnifice vir ac frater et amice carissime! Vestre notifico fraternitati, quod ego sum sanus et illaris, I quam a vestra fraternitate et amicicia multum audire dexidero $[s]$. Insuper vestre fraternitati notum facio, I quod procreatus vir Nicholaus dictus Altamont michi bene fideliter ac honorabiliter servivit, I sicut per litteras suas patentas, per me sibi factas, plus plennius apparebit. Idcirco rogo vestram caram fraternitatem diligenter per presentes, quatenus ipsum vobis recomissum seu recomendatum habeatis et ipsum in omnibus factis eius favorabiliter tractare ac adiuvare velitis ac me vobis recomissum habeatis. Valete ad vestra optata. Scriptum in Utino feria secunda ante festum sancte Margarete.

Laurencius Ratoldi de Pastoch magister dapiferorum I reginalium Romanorum et Ungarie ac comes Hontiensis.

${ }^{a-b}$ Adres na odwrociu; $\quad$ c inicjat wysokości ok. dwóch wersów kolumny tekstu.

\section{BIBLIOGRAFIA}

Bárány A., Political pilgrimage in later medieval Central Europe: a case study of a Hungarian traveller to Ireland, in: Europe and the World. Travel, Migration, Exploration, Pisa 2010.

Bárány A., Zsigmond király 1416-os angliai kísérete, Aetas, 19, 2004, nr 3-4.

Baum W., Kaiser Sigismund. Hus, Konstanz und Türkenkriege, Graz-Wien-Köln 1993.

Biskup M., Wojny polski z zakonem krzyżackim 1308-1521, Gdańsk 1993.

Caballo J., A tari késő-közepkori udvarház, Castrum Bene 2, 1990.

Cynarski S., Dzieje rodu Lanckorońskich z Brzezia od XIV do XVIII wieku, Warszawa 1996.

Dvořáková D., Čierna král'ovná. Barbora celjská (1392-1451), Budmerice-Bratislava 2013.

Dvořáková D., Rytier a jeho král’. Stibor zo Stiboric a Žigmund Luxemburský, Budmerice 2003.

Engel P., Magyarország világi archontológiája 1301-1457, t. I-II, Budapest 1996.

Engel P., Tóth N. C., Itineraria regum et reginarum (1382-1438), Budapest 2005.

Gawęda S., Początki i rola rodziny Lanckorońskich do końca średniowiecza, Zeszyty Naukowe Uniwersytetu Jagiellońskiego, Prace Historyczne, t. 89, 1989.

Gzella J., Małopolska elita władzy w okresie rządów Ludwika Węgierskiego w Polsce w latach 1370-1382, Toruń 1994.

Hoensch J. K., Kaiser Sigismund. Herrscher an der Schwelle zur Neuzeit 1368-1437, München 1996.

Jóźwiak S., Wywiad i kontrwywiad w państwie zakonu krzyżackiego. Studium nad sposobami pozyskiwania i wykorzystywania poufnych informacji w późnym średniowieczu, Malbork 2004.

Jóźwiak S., Kwiatkowski K., Szweda A., Szybkowski S., Wojna Polski i Litwy z zakonem krzyżackim 1409-1411, Malbork 2010.

Jurek T., Pismo w życiu społecznym Polski późnego średniowiecza, w: Historia społeczna późnego średniowiecza. Nowe badania, Warszawa 2011. 
Kurtyka J., O „sumach sadłowskich” i rzekomym mariażu Lanckorońskich i Tęczyńskich w początkach XV w., w: Venerabiles, nobiles et honesti. Studia z dziejów społeczeństwa Polski średniowiecznej. Prace ofiarowane Profesorowi Januszowi Bieniakowi w siedemdziesiątą rocznicę urodzin i czterdziestopięciolecie pracy naukowej, Toruń 1997.

Marzec A., Urzędnicy małopolscy w otoczeniu Władysława Łokietka i Kazimierza Wielkiego (1305-1370), Kraków 2006.

Możejko B., Ród Świnków na pograniczu polsko-krzyżackim w średniowieczu, Gdańsk 1998.

Nöbel W., Michael Küchmeister. Hochmeister des Deutschen Ordens 1414-1422, Marburg 1989.

Nowak Z. H., Współpraca polityczna państw unii polsko-litewskiej i unii kalmarskiej w latach 1411-1425, Toruń 1996.

Paravicini W., Fürschriften und Testimonia. Der Dokumentationskreislauf der spätmittelalterlichen Adelsreise am Beispiel des kastilischen Ritters Alfonso Mudarra 1411-1412, w: Studien zum 15. Jahrhundert. Festschrift fur Erich Meuthen, t. II, München 1994.

Petrauskas R., Związki personalne między możnowładztwem Polski i Litwy od końca XIV do połowy XVI wieku, w: Narodziny Rzeczypospolitej. Studia z dziejów średniowiecza i czasów wczesnonowożytnych, Kraków 2012.

Rowell S. C., Du Europos pakraščiai: Lietuvos Didžiosios Kunigaikštystės ir ispanų karalysčių ryšiai 1411-1412 m. tekstuose, Lietuvos istorijos metraštis 2003, nr 1.

Sieradzan W., Sąsiedztwo mazowiecko-krzyżackie w okresie przemian politycznych w Europie Środkowo-Wschodniej w latach 1411-1466, Toruń 1999.

Słownik historyczno-geograficzny województwa krakowskiego w średniowieczu, cz. I, z. 2, Wrocław 1983.

Sochacka A., Jan z Czyżowa, namiestnik Władysława Warneńczyka. Kariera rodziny Półkozów w średniowieczu, Lublin 1993.

Sperka J., Szafrańcowie herbu Stary Koń. Z dziejów kariery i awansu w późnośredniowiecznej Polsce, Katowice 2001.

Sroka S. A., Wojska węgierskie u granic Polski w 1410 roku, Studia Historyczne 53, 2010.

Strzelecka A., Lanckoroński Zbigniew, w: Polski słownik biograficzny, t. XVI (1971).

Szweda A., Organizacja i technika dyplomacji polskiej w stosunkach z zakonem krzyżackim w Prusach w latach 1386-1454, Torun 2009.

Szweda A., Polsko-krzyżackie kontrowersje na Krajnie w latach 1411-1422, w: Europa Środkowo-Wschodnia. Ideologia, historia a społeczeństwo, Zielona Góra 2005.

Szweda A., Zakon krzyżacki wobec Polski i Litwy w latach 1411-1414, Zeszyty Naukowe Uniwersytetu Jagiellońskiego, Prace Historyczne, t. 141, 2014, z. 2.

Szybkowski S., Kredytywa możnych polskich dla posłów do wielkiego mistrza Pawła Rusdorfa z 31 VII 1434 r. Z badań nad okresem rządów opiekuńczych w Królestwie Polskim w latach 1434-1438, Studia z Dziejów Średniowiecza 19, 2015.

Szybkowski S., Rycerscy goście z Polski na dworze wielkiego księcia Witolda - próba portretu grupy, w: Litwa i jej sąsiedzi w relacjach wzajemnych (XIII-XVI w.), Olsztyn-Gdańsk 2014.

Szybkowski S., Wielka potrzeba dokumentu. List starosty dobrzyńskiego Janusza z Kościelca do komtura golubskiego w sprawie dokumentu dotyczącego wsi Grabowo w ziemi dobrzyńskiej, Rocznik Łódzki 61, 2014.

Szymczakowa A., Dziedzice Bąkowej Góry w wieku XV, Rocznik Łódzki 50, 1993.

Szymczakowa A., Szlachta sieradzka w XV wieku. Magnifici et generosi, Łódź 1998.

Tar Lörinc pokoljárása. Középkori magyar víziók, ed. Gy. Belya, Budapest 1985.

Urzędnicy centralni i nadworni Polski XIV-XVIII wieku. Spisy, Kórnik 1992.

Urzędnicy kujawscy i dobrzyńscy XII-XV wieku. Spisy, Kórnik 2014.

Urzędnicy małopolscy XII-XV wieku. Spisy, Wrocław 1990.

Wolff A., Projekt instrukcji wydawniczej dla pisanych źródeł historycznych do połowy XVI wieku, Studia Źródłoznawcze 1, 1957.

Wyrozumski J., Przedbor z Brzezia, w: Polski słownik biograficzny, t. XXVIII (1985). 


\title{
Ein Brief des Laurentius Tari, Hofmeisters der Königin Barbara von Cilli, an Zbigniew von Brzezie, Marschall des Königreiches Polen, vom 13. Juni 1413
}

\section{Zusammenfassung}

Der hier erstmals veröffentlichte Brief stellt eines der wenigen bis heute erhaltenen Zeugnisse für Privatbriefe dar. Der Brief dokumentiert die engen Beziehungen zwischen Vertretern des mitteleuropäischen Adels im 15. Jahrhundert und hat sich im Bestand des ehemaligen Archivs der Hochmeister des Deutschen Ordens erhalten (heute im Geheimen Staatsarchiv Preußischer Kulturbesitz in Berlin-Dahlem, OBA Nr. 29049a). Bei dem Briefabsender handelte es sich um einen engen Vertrauten Kaiser Sigismunds und Hofmeister seiner Gattin Barbara von Cilli, den Gespan von Hont und Heves, Laurentius Tari († nach 1426). Der Empfänger war wiederum der Marschall des Königreiches Polen Zbigniew von Brzezie und Lanckorona ( $† 1425)$, der zur nächsten Umgebung König Wladislaus' Jagiello gehörte. Beide Korrespondenten zählten zur politischen Elite ihres jeweiligen Landes. Tari ist zudem als Pilger zu den bekanntesten europäischen Pilgerstätten bekannt. Er hielt sich 1411 nachweislich im irischen Purgatorium sancti Patrici auf, wo er seine dort erlebten Visionen schriftlich dokumentieren ließ; des weiteren bereitete er Pilgerreisen nach Santiago de Compostela (1408) und ins Heilige Land (1412) vor. Der Brief an Zbigniew von Brzezie wurde am 13. Juni 1413 in Udine, im italienischen Friaul, niedergeschrieben. In ihm empfahl Laurentius dem Empfänger einen gewissen Nikolaus gen. Altamont, der ihm vorher im ungarisch-venezianischen Krieg der Jahre 1412-1413, den der Waffenstillstand von Castelleto unterbrochen und zu dessen Zustandekommen der Aussteller beigetragen hatte, als Söldner diente. Das Schreiben hat den Empfänger wohl wegen des im September 1413 erfolgten Angriffs des Deutschen Ordens auf das Dobriner Land, dessen Starost Zbigniew 1411-1413 war, nie erreicht, und wurde daraufhin dem hochmeisterlichen Archiv auf der Marienburg einverleibt.

Übersetzt von Waldemar Könighaus

\section{A letter of Laurentius Tari, dapifer of Queen Barbara of Cilli, to Zbigniew of Brzezie, marshal of the Kingdom of Poland, dated 13 July 1413}

\begin{abstract}
The letter published here (from the collection of the Geheimes Staatsarchiv Preussisches Kulturbesitz in Berlinie-Dahlem OBA nr 29049a) is one of very few surviving examples of correspondence of Central-European elites of the $15^{\text {th }}$ century. Laurentius Tari (d. 1426) was a close advisor of Sigismund of Luxemburg as the king of Hungary. The letter was written in Udine, in the Italian Friuli, shortly after the armistice of Castaletto, between Hungary and Venice. Laurentius recommended to Zbigniew the services of one Nicolaus called Altamont. The letter most probably did not reach its addressee because of the Teutonic Knights' attack on the Land of Dobrzyń, of which Zbigniew was the starost at the time. That is why it found its way to the Teutonic Order's archives.
\end{abstract}

Translated by Rafat T. Prinke

dr hab. Sobiesław Szybkowski, prof. UG, Zakład Historii Średniowiecza Polski i Nauk Pomocniczych Historii, Instytut Historii, Uniwersytet Gdański, ul. Wita Stwosza 55, 80-952 Gdańsk, e-mail: s.szybkowski@ug.edu.pl 